\title{
Caracterização de isolados de Diplodia pinea da região Sul do Brasil por meio da compatibilidade micelial e de marcadores RAPD
}

\author{
Paula Rachel Rabelo Corrêa ${ }^{1}$; Luciano Medina Macedo²; Celso Garcia Auer ${ }^{3}$; Álvaro Figueredo dos Santos ${ }^{3}$
}

${ }^{1}$ Bióloga, Dr., Pós-graduação em Engenharia Florestal, Universidade Federal do Paraná, Curitiba-PR. ${ }^{2}$ Engenheiro Florestal, Doutor em Processos Biotecnológicos, Universidade Federal do Paraná, Curitiba-PR; ${ }^{3}$ Laboratório de Patologia Florestal, Embrapa Florestas, C.P. 319, 83411-000, Colombo-PR.

Autor para correspondência: Celso Garcia Auer (celso.auer@embrapa.br)

Data de chegada: 14/11/2014. Aceito para publicação em: 20/08/2015.

$10.1590 / 0100-5405 / 2053$

\section{RESUMO}

Corrêa, P.R.R.; Macedo, L.M.; Auer, C.G.; Santos, A.F. dos. Caracterização de isolados de Diplodia pinea da região Sul do Brasil por meio da compatibilidade micelial e de marcadores RAPD. Summa Phytopathologica, v.42, n.1, p.97-99, 2016.

O objetivo do trabalho foi caracterizar quatro isolados de Diplodia pinea da região Sul do Brasil e estimar sua variabilidade genética, baseados na compatibilidade vegetativa e marcadores RAPD. Na compatibilidade vegetativa, os isolados foram pareados em placas de Petri com meio BDA e formaram linhas escuras quando incompatíveis e linhas claras cotonosas quando incompatíveis. Para a caracterização molecular dos isolados, a extração de DNA foi realizada em amostras obtidas de micélio cultivado em meio BDA dos isolados originais e os monospóricos derivados. O DNA das amostras foi avaliado em reação de polimerase em cadeia (PCR), utilizando onze sequências diferentes de primers RAPD inespecíficos. O agrupamento dos morfotipos foi realizado pelo método UPGMA e coeficiente de similaridade de Jaccard. Somente um marcador RAPD mostrou polimorfismo, indicando que os isolados apresentam pequena divergência genética, porém suficiente para indicar mais de morfotipo presente.

Palavras-chave: diversidade genética, morfotipo, Pinus, seca de ponteiro.

\section{ABSTRACT}

Corrêa, P.R.R.; Macedo, L.M.; Auer, C.G.; Santos, A.F. dos. Characterization of Diplodia pinea isolates from the South region of Brazil by means of mycelial compatibility and RAPD markers. Summa Phytopathologica, v.42, n.1, p.97-99, 2016.

The aim this study was to characterize four isolates of Diplodia pinea from the South region of Brazil and to estimate their genetic diversity, based on vegetative compatibility and RAPD markers. For vegetative compatibility, isolates were paired on Petri dishes containing PDA medium and formed dark lines when incompatible and cottony light lines when compatible. For the molecular characterization of isolates, DNA extraction was performed for samples obtained from mycelium grown on PDA medium of original and derived monosporic isolates. The DNA of samples was assessed according to polymerase chain reaction (PCR), using eleven different sequences of nonspecific RAPD primers. The grouping of morphotypes was performed according to the UPGMA method and the Jaccard similarity coefficient. Only one RAPD marker showed polymorphism, indicating that the genetic diversity of isolates is low but enough to indicate more than the one present morphotype.

Keywords: genetic diversity, morphotype, Pinus, shoot dieback.

Diplodia pinea (Desm.) J. Kickx (= Sphaeropsis sapinea (Fr.) Dyko $\&$ B. Sutton) é um patógeno causador de seca de ponteiros e morte apical em Pinus no Brasil (3). Sua reprodução é assexuada, com morfotipos e linhagens clonais, que diferem na patogenicidade ao hospedeiro (2). Para sua diferenciação utiliza-se a compatibilidade vegetativa, característica fenotípica usada no estudo de diversidade genotípica e como rápido marcador genotípico entre populações de alguns fungos $(8,9)$. Outro critério é a avaliação da diversidade genética é baseada em marcadores moleculares.

Entre os marcadores moleculares disponíveis, os marcadores RADP (Random Amplified Polymorfic DNA) se baseiam na amplificação aleatória de fragmentos de DNA em reação de polimerase cadeia (PCR), o que possibilita a verificação da existência de polimorfismos genéticos em várias regiões genômicas de um organismo de interesse, simultaneamente, em uma mesma reação de PCR. A utilização de dois ou mais marcadores independentes como grupos de compatibilidade vegetativa, marcadores de DNA como microssatélites ou padrões de DNA podem separar isolados obtidos de linhagem clonal ou provenientes de reprodução sexual e tem-se revelado uma técnica eficiente. Desse modo, Burgess et al. (1) analisaram a diversidade genotípica de populações nativas e introduzidas de $D$. pinea isoladas de Pinus radiata da Austrália, Nova Zelândia e África do Sul.

Pela escassez de informações sobre $D$. pinea no Brasil, este trabalho teve como objetivo avaliar a variabilidade genética de isolados de $D$. pinea da região Sul do Brasil, com base na compatibilidade vegetativa e marcadores RAPD.

Quatro isolados do fungo foram utilizados: SS1 (Pinus taeda L., São José do Ouro/RS); SS2 (Pinus greggii Engelm. \& Parlat., Rancho Queimado/SC); SS3 (Pinus maximinoi H. E. Moore, Santa Maria do 
Oeste/PR) e SS4 (Pinus sp., Curitiba/PR).

No teste de compatibilidade vegetativa, os isolados foram cultivados em meio BDA (extrato comercial de batata-dextrose-ágar, $39 \mathrm{~g}$; água destilada, $1000 \mathrm{~mL}$ ), e posteriormente foram produzidos isolados monospóricos de cada um dos quatro isolados originais, pelo plaqueamento individual de conídios retirados de picnídios produzidos em meio de cultura. Discos com micélio-ágar dos isolados originais, de cinco mm de diâmetro, juntamente com seus derivados monospóricos com sete a dez dias de crescimento, foram transferidos para placas de Petri com meio BDA a uma distância de $10 \mathrm{~mm}$ entre si. Os discos foram distribuídos nas placas, de forma que todos os isolados fossem confrontados. As placas foram incubadas por quatro dias em câmara BOD a $25^{\circ} \mathrm{C}$, no escuro.

Os isolados foram considerados como compatíveis $(\mathrm{CV})$ quando se formou uma densa linha clara ou cinza com entrelaçamento micelial entre eles revelando crescimento contínuo. Os isolados foram considerados incompatíveis (ICV) quando se formou uma linha escura bem definida entre os isolados confrontados, com posterior formação de picnídios. Considerou-se média compatibilidade vegetativa (MCV) quando houve formação de uma linha fina e escura entre os isolados e alguns picnídios.

Para a caracterização molecular dos isolados, a extração de DNA foi realizada em amostras obtidas de micélio cultivado em meio BDA, por meio de raspagem direta dos isolados monospóricos, juntamente com os isolados originais. Analisou-se os isolados SS1 (monospóricos 1 a 4), SS2 (monospóricos 5 a 8), SS3 (monospóricos 9 a 12) e SS4 (monospóricos 13 a 15).

Para a amplificação do DNA, pela técnica de RAPD, utilizouse um mix com os seguintes produtos: 1,5 unidades da enzima Taq DNApolimerase; $5 \mu \mathrm{M}$ para cada $\mathrm{dNTP} ; 3,0 \mu \mathrm{M}$ de cloreto de magnésio (MgCl2); 0,4 $\mu \mathrm{M}$ de primers $20 \mathrm{mM}$ de Tris- $\mathrm{HCl} \mathrm{pH} 8,4 ; 5 \mathrm{mM} \mathrm{KCl}$ e $10 \mathrm{ng}$ de DNA por $25 \mu \mathrm{L}$ de reação. Foram utilizados 35 ciclos nas seguintes condições: 1 minuto a $92^{\circ} \mathrm{C} ; 1,5$ minutos a $37^{\circ} \mathrm{C}$ e 1 minuto a $72{ }^{\circ} \mathrm{C}$. Foram utilizados 5 minutos a $94{ }^{\circ} \mathrm{C}$ para desnaturação inicial e 5 minutos a $72{ }^{\circ} \mathrm{C}$ de extensão final. A mistura contendo $15 \mu \mathrm{L}$ de cada amostra mais $5 \mu \mathrm{L}$ de tampão de carregamento foi aplicada no gel $(1,5 \%)$. Nas extremidades, aplicou-se um marcador de peso molecular Ladder $100 \mathrm{pb}$ (MPM). A corrida do DNA no gel foi realizada sob voltagem constante de $3 \mathrm{~V} / \mathrm{cm}$.

Foram utilizadas como sequências inicializadoras para a reação de PCR-RAPD, onze primers da série operon, amplamente empregados para a verificação de polimorfismos em microrganismos. Os 11 primers utilizados de sequências 5'-3' foram OPA3 (AGTCAGCCAC), OPA7 (GAAACGGGTG), OPA10 (GTGATCGCAG) e OPA16 (AGCCAGCGAA); OPX11 (CAATCGCCGT), OPX12 (CCTTGACGCA), OPX13 (CAGCACCCAC), OPX14 (TCTGTGCTGG), OPX17 (GACCGCTTGT) e OPX19 (CAAACGTCGG) e OPAX 19 (CAAACGTCGG).

O agrupamento dos morfotipos foi realizado pelo método UPGMA (Unweighted Pair-Group Method with Arithmetical Average), utilizando o coeficiente de similaridade de Jaccard (6), onde maior a semelhança entre dois morfotipos, maior o valor do coeficiente de similaridade (4). Esse agrupamento é um modelo hierárquico que permite a construção de dendrogramas (10), e laborados com auxílio do programa NTSYS-PC.

O teste de compatibilidade vegetativa revelou a existência de incompatibilidade (ICV) entre isolados originais e entre os monospóricos dos diferentes isolados originais, e também entre alguns monospóricos provenientes do mesmo isolado original, pela formação de uma linha escura indicando a ausência de contato entre as colônias e a formação de picnídios (Figura 1A). Porém, nos isolados compatíveis observou-se a formação de um micélio de aspecto cotonoso contínuo (CV) entre eles, que ao microscópio estereoscópico revelou ser um entrelaçamento das hifas na região de contato entre as colônias (Figura 1A). Entre os isolados monospóricos oriundos de um mesmo isolado original verificou-se a predominância de CV. Em casos duvidosos, formou-se uma linha escura e rala (Figura 1B), considerada como compatibilidade vegetativa média (CVM). Quando as placas foram mantidas em BOD por um período superior a 30 dias, houve formação de picnídios entre os isolados originais SS1, SS2, SS3, SS4. Tais resultados foram verificados por Burgess et al. (1).

Não foi possível fazer a variação dos perfis eletroforéticos, pois 10 primers RAPD apresentaram apenas bandas monomórficas, a exceção de um que apresentou bandas polimórficas. O comportamento monomórfico ocorre quando se formam perfis de bandas similares entre si (4). Como este fungo possui apenas a reprodução assexuada, era esperado este comportamento monomórfico. Assim, entende-se que os isolados possuem uma bagagem genética homogênea. No entanto, somente um primer apresentou polimorfismo e os resultados serviram para uma interpretação preliminar sobre o perfil genético

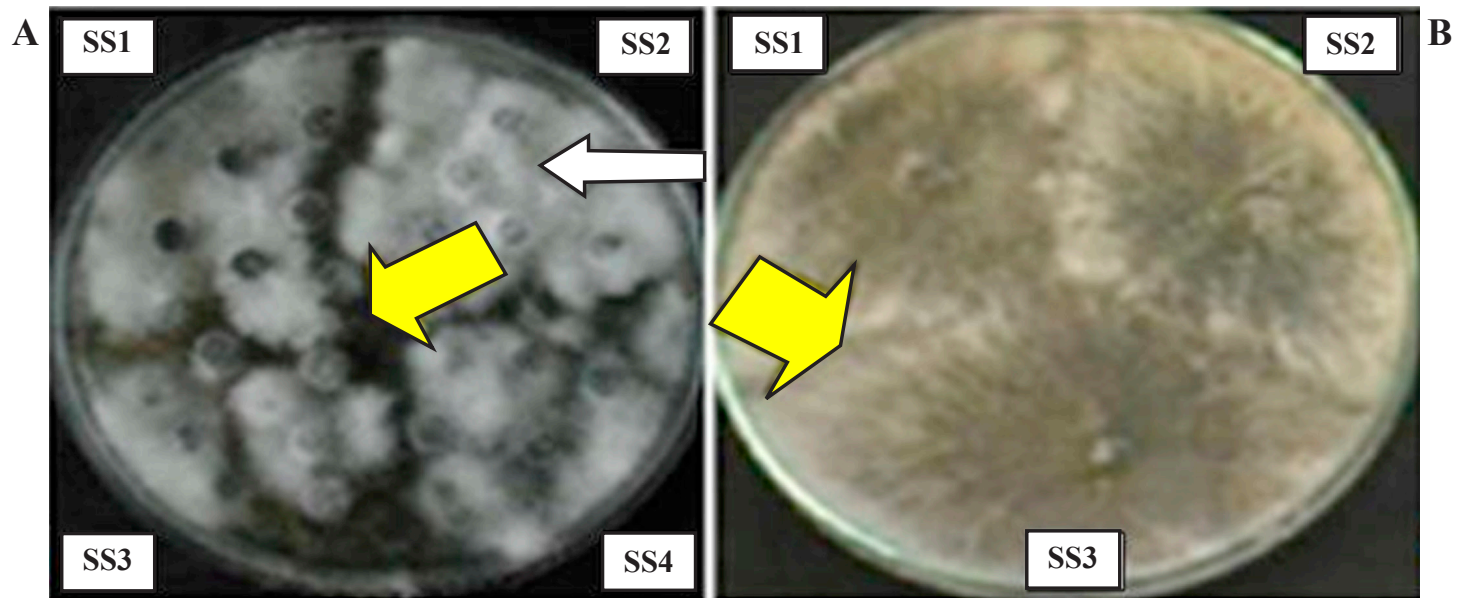

Figura 1. Reação de compatibilidade vegetativa entre isolados de Diplodia pinea em meio ágar- água. A. Incompatibilidade vegetativa (ICV, seta amarela) e Compatibilidade vegetativa (CV, seta branca). B. Média compatibilidade vegetativa (MCV, seta amarela). 


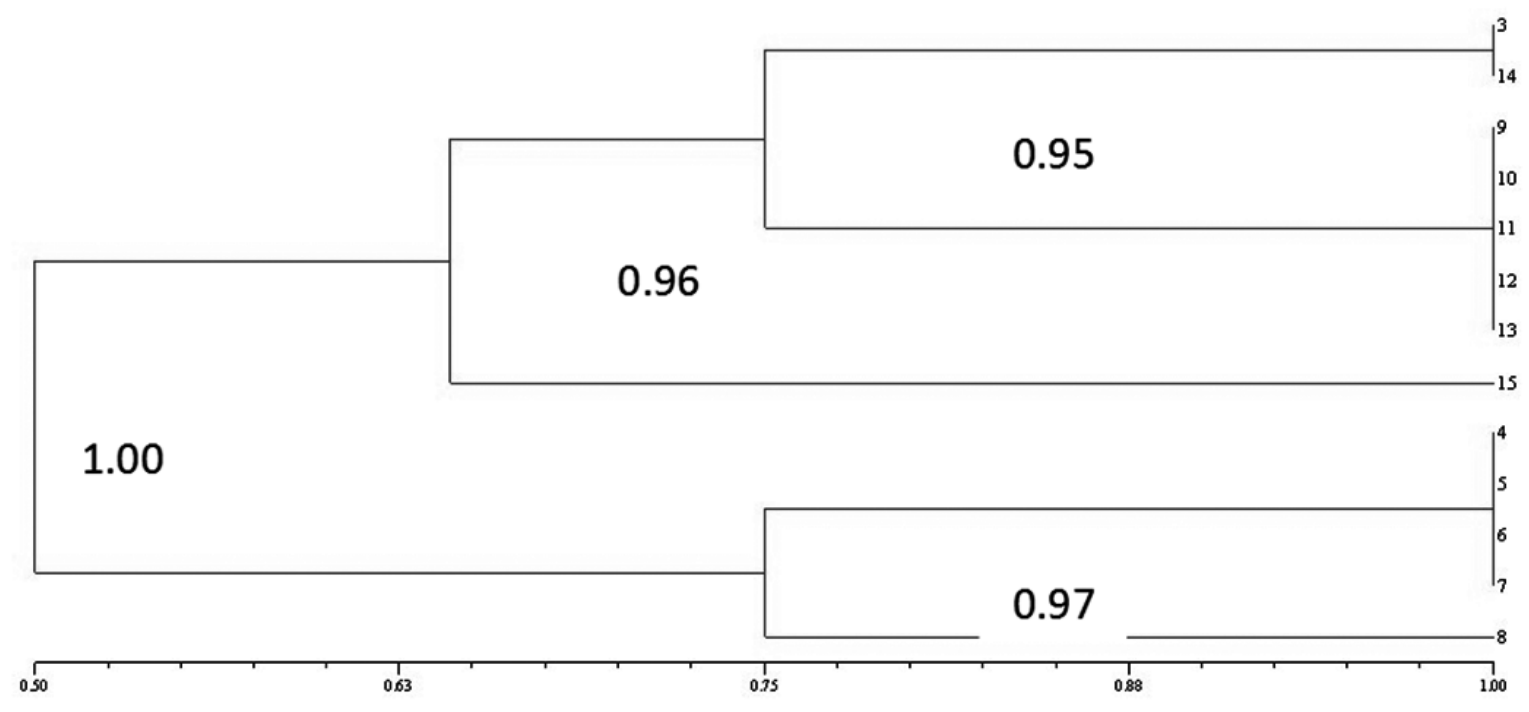

Figura 2. Dendrograma de similaridade genética entre 4 isolados de Diplodia pinea da região Sul do Brasil. Os números correspondem aos isolados: 4 monospóricos 3 (SS1); 5, 6, 7 - monospóricos 1, 2 e 3 (SS2); 8 - isolado original SS2; 9, 10 e 11 - monospóricos 1, 2 e 3 (SS3); 12 - isolado original SS3; 13, 14 e 15 - monospóricos (SS4). Não foi possível a extração do DNA dos isolados 1, 2 e o original SS1.

dos isolados de $D$. pinea.

O dendrograma mostrou a formação de três agrupamentos geográficos no ponto de corte de $75 \%$ de similaridade (Figura 2). No nó superior, ficaram agrupados os isolados mais similares entre si, quando comparados com o terceiro grupo de isolados monospóricos 4 (SS1) e 5, 6, 7 e 8 (SS2). Não foi possível extrair do DNA dos isolados monospóricos 1 e 2 de SS1 e a cultura original SS4.

Os isolados monospóricos de Rancho Queimado (SS2) apresentaram-se separados do isolado original, mas com a mesma similaridade genética média de $75 \%$. Este tipo de comportamento do isolado original SS2 pode indicar a existência de variabilidade clonal. No caso dos isolados monospóricos de São José do Ouro (SS1), o isolado monospórico 3 ficou agrupado com os isolados monospóricos derivados de Rancho Queimado (SS2), o que seria indício de uma origem comum. O isolado monospórico 3 apresentou uma grande divergência genética e tendência similar de variabilidade no estudo de CV. Outro fato verificado foi que o isolado original de São José do Ouro (SS1) se agrupou com o isolado monospórico 2 do grupo dos isolados de Curitiba (SS4).

Estas divergências podem ser explicadas pela presença de linhagens clonais dentro de populações, fato comentado por Mcdonald (7) para fungos com reprodução assexuada. A ausência de diversidade entre os isolados monospóricos produzidos com o isolado de Santa Maria do Oeste (SS3) pode ser considerada como uma evidência da uma única origem.

A análise das bandas do perfil com polimorfismo revelou, apesar do pequeno número de isolados, a mesma divergência genética mostrada nos testes de compatibilidade vegetativa, sendo esta divergência mais evidente entre os isolados de SS4 e SS1. De acordo com a origem dos isolados, a separação geográfica poderia ter promovido divergências entre isolados segundo as pressões ambientais do seu novo habitat. $\mathrm{O}$ teste de compatibilidade vegetativa entre isolados mostrou um padrão regionalizado na divergência genética entre os quatro isolados obtidos na região Sul do Brasil. Como D. pinea apresenta apenas reprodução assexuada, que não favorece a diversidade, a divergência genética encontrada nestes isolados não poderia ser explicada pelo modo de reprodução, nem explicada pela distância geográfica entre os isolados, porque é recente e não foi acompanhada por um longo e intenso isolamento sexual. Portanto, na ausência de reprodução sexual, a divergência genética apresentada pelo fungo $D$. pinea pode ser uma consequência de várias introduções do fungo juntamente com as introduções de Pinus realizadas no Brasil entre as décadas de 1940 e 1980. Considerando estudos de Burgess et al. $(1,2)$, esta divergência genética indicaria a existência de mais de um morfotipo no Brasil.

\section{REFERÊNCIAS BIBLIOGRÁFICAS}

1. Burgess, T.I.; De Wet, J.; Wingfield, M.J.; Coutinho, T.A.; Wingfield, B.D. Characterization of Sphaeropsis sapinea isolates from South Africa, Mexico and Indonesia. Plant Disease, Saint Paul, v.84, n.2, p. 151-156, 2000.

2. Burgess, T.; Wingfield M.J.; Wingfield, B.W. Global distribution of Diplodia pinea genotypes revealed using sequence repeat (SSR) markers. Australasian Plant Pathology, Melbourne, v.33, p.513-519, 2004.

3. Corrêa, P.R.R.; Auer, C.G.; Santos, A.F. dos; Higa, A.R. Seleção precoce de progênies de Pinus radiata a Sphaeropsis sapinea. Ciência Florestal, Santa Maria, v.22, n.2, p.275-281, 2012.

4. Glienke, C. Variabilidade genética no fungo endofítico Guinardia citricarpa Kiely detectada por RAPD. 1995. 115 f. Dissertação (Mestrado em Genética)-Setor de Ciências Biológicas, Universidade Federal do Paraná, Curitiba.

5. Ivory, M.H. Records of foliage pathogens of Pinus species in tropical countries. Plant Pathology, London, n.43, p.511-518, 1994.

6. Jaccard, P. Nouvelles recherches sur la distribution florale. Bulletin Société Vaudoise des Sciences Naturelles, Lausanne, v.44, n.2, p.223-270, 1908.

7. McDonald, B.A. The population genetics of fungi: tools and techniques. Phytopathology, Saint Paul, v.87, n.4, p.448-453, 1997.

8. McDonald, B.A.; Linde, C. Pathogen populations genetics evolutionary potential and durable resistance. Annual Review of Phytopathology, Palo Alto, n.40, p. 349-379, 2002.

9. Schafer, M.R.; Kohn, L. M. An optimized method for mycelial compatibility testing in Sclerotinia sclerotiorum. Mycologia, New York, v.98, n.4, p.593-597, 2006.

10. Sneath, P.H.; Sokal, R.R. Numerical taxonomy. San Francisco: W. H. Freeman, 1973. 573p. 